\title{
UPAYA PENINGKATAN PENGETAHUAN DAN SIKAP KADER DALAM PENCEGAHAN PEMBERIAN MAKANAN PRALAKTAL PADA BAYI 0-3 HARI
}

\author{
Iis Ria Fitriani, Epti Yorita, Wisuda Andeka Marleni \\ Politeknik Kesehatan Kementerian Kesehatan Bengkulu, Jurusan Kebidanan, \\ Jalan Indragiri Nomor 03 Padang Harapan Bengkulu \\ e-mail: alichiamom2014@gmail.com
}

\begin{abstract}
Infant Mortality in Bengkulu Province is still high, this can be prevented through breastfeeding as a staple food in infants 0-6 months without other complementary foods because breast milk boosts immune status for infants and thus can reduce mobility and mortality rates but exclusive ASI coverage still low, this is influenced by pralactal feeding in infants 0-3 days of birth. Research Objective to increase knowledge and attitude of cadre through training as promotion effort of prevention of pralactal food in 0 3 days old baby. Quasi pre and post test experiments with comparison groups. The study population were all cadres in Talang Tinggi Public Health Center, which were 50 people in Talang Tinggi Public Health Center, Seluma District with experimental group samples were cadres who were given training by using module and control group were cadres who were trained by using lecture and question and answer method. There is an average difference of attitude and knowledge before and after intervention in the cadres given training on prevention of pralactal food in infants 0-3 days. There is an effect of training on prevention efforts of pralactal feeding using modules with cadre attitude. Puskesmas should increase the promotion of prevention of pralactal food to change cadre attitude to support program exclusive breastfeeding.
\end{abstract}

Keywords: Cadre, Training, Pralactal Food Prevent

\begin{abstract}
Abstrak: Kematian Bayi di Provinsi Bengkulu masih tinggi, hal ini dapat di cegah melalui pemberian ASI sebagai makanan pokok pada bayi 0-6 bulan tanpa makanan pendamping lain karena ASI meningkatkan status kekebalan tubuh bagi bayi dan sehingga dapat menurunkan angka mobiditas dan mortalitas tetapi cakupan ASI eksklusif masih rendah, hal ini dipengaruhi oleh pemberian makanan pralaktal pada bayi 0-3 hari pertama kelahiran. Tujuan Penelitian untuk meningkatan pengetahuan dan sikap kader melalui pelatihan sebagai upaya promosi pencegahan makanan pralaktal pada bayi umur 0-3 hari. Kuasi eksperimen pre dan post test dengan kelompok pembanding. Populasi penelitian adalah semua kader di Wilayah Puskesmas Talang Tinggi yang berjumlah 50 orang di wilayah Puskesmas Talang Tinggi Kabupaten Seluma dengan sampel kelompok eksperimen adalah kader yang diberikan pelatihan dengan menggunakan modul dan kelompok kontrol adalah kader yang diberikan pelatihan dengan menggunakan metode ceramah dan Tanya jawab. Terdapat perbedaan rata-rata sikap dan pengetahuan sebelum dan sesudah intervensi pada kader yang diberikan pelatihan tentang upaya pencegahan makanan pralaktal pada bayi 0-3 hari. Ada pengaruh pelatihan upaya pencegahan pemberian makanan pralaktal dengan menggunakan modul dengan sikap kader. Pihak Puskesmas harus meningkatkan promosi pencegahan makanan pralaktal untuk merubah sikap kader agar mendukung program ASI eksklusif.
\end{abstract}

Kata Kunci: Kader, Pelatihan, Pencegahan Makanan Pralaktal

Angka Kematian Bayi (AKB) dan Angka Kematian Balita (AKABA) di Indonesia saat ini masih tinggi dibandingkan dengan AKB dan AKABA dinegara lain di Asia Tenggara. Berdasarkan data SDKI 2012, AKB di Indonesia sebesar 32/100.000 kelahiran hidup, sedangkan di Provinsi Bengkulu 
AKB bayisebesar 29/100.000 kelahiran hidup, angka ini lebih tinggi dari AKB secara Nasional dan AKB di Provinsi Bangka Belitung dan Sumatera Barat yang hanyasebesar 27/100.000 balita. (SDKI 2012).

Salah satu upaya yang dapat dilakukan untuk mencegah kematian bayi adalah dengan memberikan ASI sebagai makanan pokok pada bayi 0-6 bulan tanpa makanan pendamping lain atau susu formula serta dilanjutkan sampai Bayi berumur 2 tahun karena ASI meningkatkan status kekebalan tubuh bagi bayi. Berdasarkan data Riskesdas 2013 cakupan pemberian ASI eksklusif di Indonesia hanya 54\%. DI Provinsi Bengkulu Cakupan pemberian ASI eksklusif sebesar 50,76\%, pada tahun 2014 sebesar 77,8\% dan pada tahun 2015 sebesar 25\%. Di Kabupaten Seluma cakupan pemberian ASI ekslusif tahun 2014 terendah di Puskesmas Dermayu dan tertinggi di Puskesmas Muara Maras diikuti Puskesmas Kemang Mumpo dan Puskesmas dusun Tengah. Pada tahun 2015 terendah di Puskesmas Dermayu dan tertinggi di Puskesmas Muara Maras.

Rendahnya pencapaian ASI eksklusif dipengaruhi oleh banyak faktor. Penelitian yang telah menemukan faktor yang mepengaruhi pemberian ASI eksklusif antara lain faktor ibu yaitu usia, pendidikan, pekerjaan, sosialekonomi, penolong persalinan, tempat pesalinan, pemakaian kontrasepsi dan faktor promosi ASI dan promosi susu formula ${ }^{3}$. Pemberian makanan/minuman pralaktal adalah praktik budaya yang sering dilakukan dan merupakan salah satu faktor utama kegagalan pelaksanaan ASI eksklusif. Kegagalan ASI eksklusif telah dimulai sejak 3 hari pertama kelahiran yaitu pada saat makanan/minuman pralaktal diberikan hal ini dikarenakan pengetahuan dan pengalaman ibu yang kurang tentang ASI eksklusif. Pemberian makanan pralaktal pada bayi baru lahir adalah masih terbatasnya tenaga konselor ASI serta belum maksimalnya kegiatan edukasi, sosialisasi, advokasi dan kampanye terkait pemberian ASI yang dapat dilakkan oleh kader posyandu karena pentingnya peranan kader dalam memberdayakan masyarakat guna menurunkan tingkat kematian bayi dan balita di Indonesia tidak diragukan lagi tetapi peran ayang dilaksankan oleh kader sat ini belum maksimal.

Kader diharapkan dapat

memberdayakan masyarakat guna menurunkan tingkat kematian anak maka kader perlu diberikan materi pelatihan yang mencakup tentang pentingnya pemberian ASI eksklusif hingga usia 6 bulan, mempertahankan pemberian ASI hingga usia 2 tahun atau lebih melalui metode pelatihan diberikan secara interaktif dengan teknik pembelajaran orang dewasa sehingga dapat meningkatkan pengetahuan dan ketrampilan mereka. Sehingga kader perlu diberdayakan melalui peningkatan pengetahuan dan sikap kader dalam pencegahan pemberian makanan pralaktal pada bayi 0-3 hari di Wilayah Puskesmas Talang Tinggi Kabupaten Seluma Tahun 2016.

\section{BAHAN DAN CARA KERJA}

Desain penelitian: kuasi eksperimen pre dan post test dengan kelompok kontrol. Populasi penelitian adalah kader posyandu di wilayah Puskesmas Talang Tinggi Kabupaten Seluma dengan sampel kader posyandu di Wilayah Puskesmas talang Tinggi dengan kelompok eksperimen adalah kader yang diberikan pelatihan pencegahan makanan pralaktal dengan menggunakan modul sedangkan kelompok kontrol adalah kader yang dilakukan pelatihan dengan menggunakan ceramah. Sampel diambil dengan purposif sampel. Pengumpulan data dilakukan melalui kuesioner, pre dan post test, analisis data dengan univariat dan bivariat uji paried $t$. 


\section{HASIL}

Tabel 1. Distribusi Frekuensi pengetahuan dan sikap kader tentang pencegahan pemberian makanan pra laktal di Puskesmas Talang Tinggi Kabupaten Seluma

\begin{tabular}{ccccccc}
\hline $\begin{array}{c}\text { Variabel } \\
\text { Pengetahuan } \\
\text { Kelompok Intervensi }\end{array}$ & $\mathbf{n}$ & $\mathbf{\%}$ & Mean & SD & Min & Max \\
\hline $\begin{array}{l}\text { Sebelum Perlakuan } \\
\quad \text { Sesudah Perlakuan }\end{array}$ & 22 & 100 & 15.64 & 1.916 & 11 & 18 \\
Kelompok Pembanding & 22 & 100 & 17.68 & 1.393 & 14 & 20 \\
$\quad$ Sebelum Perlakuan & 22 & 100 & 16.18 & 1.368 & 13 & 18 \\
$\quad$ Sesudah Perlakuan & 22 & 100 & 17.82 & 1.368 & 15 & 20 \\
Sikap & & & & & & \\
$\quad$ Kelompok Intervensi & 22 & 100 & 21.27 & 3.954 & 16 & 29 \\
$\quad$ Sebelum Perlakuan & 22 & 100 & 22.82 & 4.261 & 15 & 30 \\
$\quad$ Sesudah Perlakuan & & & & & & \\
Kelompok Pembanding & 22 & 100 & 20.77 & 3.954 & 14 & 28 \\
$\quad$ Sebelum Perlakuan & 22 & 100 & 23.59 & 4.261 & 28 & 30 \\
$\quad$ Sesudah Perlakuan & & &
\end{tabular}

Berdasarkan tabel 1. dapat dilihat bahwa terjadi peningkatan pengetahuan dan sikap sebelum dan sesudah perlakuan baik pada kelompok intervensi maupun kelompok pembanding. Nilai minimal skor pengetahuan pada kelompok intervensi lebih rendah dari kelompok pembanding hal ini berarti sebelum intervensi pengetahuan pada kelompok pembanding memang lebih tinggi dibandingkan kelompok perlakuan.

Tabel 2. Perbedaan Pengetahuan dan Sikap Kader Tentang Pencegahan Pemberian Makanan Pralaktal Sebelum dan Setelah Intervensi di Puskesmas Talang Tinggi Kabupaten Seluma

\begin{tabular}{|c|c|c|c|c|c|c|c|c|}
\hline Variabel & $\mathrm{N}$ & $\%$ & Min & $\operatorname{Max}$ & Mean & $\begin{array}{l}\text { Beda } \\
\text { mean }\end{array}$ & $S D$ & Nilai $p$ \\
\hline \multicolumn{9}{|c|}{ Sikap Kelompok Intervensi } \\
\hline Sebelum & 22 & 100 & 16 & 29 & 21.27 & \multirow[b]{2}{*}{1.55} & 3.954 & \multirow[b]{2}{*}{0.000} \\
\hline Sesudah & 22 & 100 & 15 & 30 & 22.82 & & 4.261 & \\
\hline \multicolumn{9}{|c|}{ Sikap Kelompok Pembanding } \\
\hline Sebelum & 22 & 100 & 14 & 28 & 20.77 & \multirow{2}{*}{2.82} & 3.954 & 0.834 \\
\hline Sesudah & 22 & 100 & 28 & 30 & 23.59 & & 4.261 & \\
\hline \multicolumn{9}{|c|}{ Pengetahuan Kelompok Intervensi } \\
\hline Sebelum & 22 & 100 & 11 & 18 & 15.64 & \multirow[t]{2}{*}{2.04} & 1.916 & \multirow[t]{2}{*}{0.065} \\
\hline Sesudah & 22 & 100 & 14 & 20 & 17.68 & & 1.393 & \\
\hline \multicolumn{9}{|c|}{ Pengetahuan Kelompok Pembanding } \\
\hline Sebelum & 22 & 100 & 13 & 18 & 16.18 & \multirow{2}{*}{1.64} & 1.368 & 0.219 \\
\hline Sesudah & 22 & 100 & 15 & 20 & 17.82 & & 1.368 & \\
\hline
\end{tabular}

Terdapat perbedaan rata-rata sikap sebelum dan sesudah pada kelompok intervensi. Hasil uji statistik menunjukkan bahwa ada perbedaan yang bermakna 
secara statistik pengetahuan kader sebelum dan setelah pelatihan tentang makanan pralaktal dengan menggunakan modul dengan nilai $p=0.00$ dan beda mean 1.55 . Tabel diatas juga menunjukkan terjadi peningkatan rata-rata sikap sebelum dan sesudah pemberian pelatihan dengan metode ceramah, tetapi hasil uji statistik menunjukkan tidak ada perbedaan yang signifikan sikap kader tentang sebelum dan setelah pelatihan pencegahan pemberian makanan pralaktal menggunakan metode ceramah dengan nilai $p=0.384$.

Tabel 3. Perbedaan Pengetahuan dan Sikap Kader Tentang Pencegahan Pemberian Makanan Pralaktal Setelah Intervensi Pada kelompok perlakuan dan kelompok pembanding di Puskesmas Talang Tinggi Kabupaten Seluma

\begin{tabular}{ccccccccc}
\hline Variabel & N & \% & Mean & SD & SE & $\begin{array}{c}\text { Beda } \\
\text { mean }\end{array}$ & Nilai $\boldsymbol{p}$ & $\mathbf{9 5} \boldsymbol{C I}$ \\
\hline $\begin{array}{c}\text { Pengetahuan } \\
\text { Modul }\end{array}$ & 22 & 100 & 17.68 & 3.954 & 0.29 & 0.13 & 0.901 & $-0.70-0.97$ \\
$\quad$ Ceramah & 22 & 100 & 17.82 & 4.261 & 0.29 & & & \\
Sikap & & & & & & & & $-1.57-3.11$ \\
$\quad$ Modul & 22 & 100 & 20.77 & 3.954 & 0.00 & 0.77 & 0.301 & \\
$\quad$ Ceramah & 22 & 100 & 22.82 & 4.261 & 0.72 & & & \\
\hline
\end{tabular}

Tabel 3. juga menunjukkan bahwa tidak ada perbedaan yang bermakna secara statistik antara pelatihan kaderC menggunakan modul dengan pelatihan kader menggunakan ceramah terhadap pengetahuan kader tentang pencegahan makanan pralaktal dengan nilai $\mathrm{p}=0.901$ beda mean 0.13. Dari tabel diatas juga menunjukkan bahwa tidak ada perbedaan yang bermakna secara statistik antara pelatihan kader menggunakan modul dengan ceramah terhadap sikap kader tentang pencegahan makanan pralaktal dengan nilai $\mathrm{p}=0.901$ beda mean 0.13 .

\section{PEMBAHASAN}

Hasil penelitian ini menemukan terjadi peningkatan pengetahuan dan sikap sebelum dan sesudah perlakuan baik pada kelompok intervensi maupun kelompok pembanding. Nilai minimal skor pengetahuan pada kelompok intervensi lebih rendah dari kelompok pembanding hal ini berarti sebelum intervensi pengetahuan pada kelompok pembanding memang lebih tinggi dibandingkan kelompok perlakuan. hal ini kemungkinan disebabkan seringnya kader mengikuti sosialisasi tentang ASI eksklusif, selain itu kader posyandu dibekali dengan buku kader yang memuat tentang promosi kesehatan termasuk tentang ASI eksklusif. Adanya perbedaan hasil pada kedua variabel ini kemungkinan karena perbedaan media yang digunakan. Media modul didesain dengan menarik dan ringkas berfokus pada makanan pralaktal dan ASI eksklusif, sehingga mudah diterima. Menurut Kemenkes, 2015 bahwa media promosi kesehatan adalah semua sarana atau upaya untuk menampilkan pesan atau informasi yang ingin disampaikan oleh komunikator, baik itu melalui media cetak, elektronik dan media luar ruang, sehingga sasaran dapat meningkat pengetahuannya yang akhirnya diharapkan dapat berubah perilakunya kearah positif terhadap kesehatannya.

Hasil penelitian ini berbeda dengan penelitian terdahulu yang menemukan kader kesehatan belum merealisasikan promosi kesehatan program ASI eksklusif secara maksimal karena rendahnya pengetahuan. Penelitian ini merekomendasikan untuk meningkatkan kompetensi kader dapat dilakukan melalui pelatihan, sebaiknya kader diberikan pelatihan manajemen laktasi sehingga kader dapat melakukan pendekatan yang sesuai yang pernah dilakukan. 
Hasil penelitian ini menemukan bahwa terdapat pengaruh pemberian promosi kesehatan dengan modul terhadap sikap kader tentang pencegahan pemberian makanan pralaktal. Hasil penelitian ini sesuai dengan penelitian yang lalu bahwa terdapat perbedaan rata-rata skor kader sebelum dan setelah penyuluhan ASI eksklusif dengan menggunakan modul dibandingkan dengan kelompok pembanding.

Hasil penelitian ini membuktikan bahwa pemberian promosi kesehatan melalui modul berkontibusi untuk merubah sikap kader dalam pencegahan pemberian makanan pralaktal sebsesar 1.55 kali dibandingkan dengan promosi kesehatan melalui ceramah. Hal ini dikarenakan modul yang digunakan untuk pelatihan dapat dibawa pulang oleh kader sehingga dapat mengulangi kembali pesan promosi yang berikan, ini berpeluang merubah sikap kader menjadi lebih mendukung pencegahan pemberian makanan pralaktal, sesuai dengan penelitian Kusuma (2016), bahwa pengetahuan yang baik akan berpengaruh terhadap sikap kader yang mendukung pencegahan makanan pralaktal. Sikap kader yang positif akan berdampak pada kemauan kader untuk selalu proaktif dan bertanggung jawab dalam memberikan sosialisasi pentingnya pemberian ASI eksklusif pada bayi 0-6 bulan.

Hasil penelitian ini menemukan tidak ada perbedaan pemberian promosi kesehatan dengan menggunakan modul atau ceramah pada kelompok intervensi dan kelompok pembanding dengan pengetahuan kader tentang pemberian makanan pralaktal. Hal ini berarti pengethauan dan sikap tidak berhubungan dengan jenis media yang digunakan dalam penelitian ini apakah media leaflet atau kalender. Hasil ini menjadi tidak bermakna karena kemungkinan paparan pengetahuan kader tentang ASI eksklusif atau makanan pralaktal sebelum intervensi penelitian ini dilakukan menyebabkan kader telah memiliki pengetahuan yang tinggi serta sikap yang mendukung sehingga ketika diuji secara statistik tentang media yang efektif pada penelitian ini tidak menimbulkan pengaruh yang signifikan. Berdasarkan hasil penelitian ini, peneliti merekomendasikan bahwa pelatihan kader dengan menggunakan modul harus tetap dilakukan karena terjadi perbedaan yang bermakna secara statistik pada kelompok perlakukan.

Pelatihan perlu dilakukan sebagai upaya pemantapan pengetahuan kader sehingga dapat merubah sikap yang mendukung yang diharapkan mampu mempengaruhi perilaku kader dalam melakukan upaya pencegahan pemberian makanan pralaktal pada bayi 0-3 hari. Hal ini sejalan dengan hasil penelitian terdahulu, pengetahuan kader berperan penting dalam promosi ASI ekslusif. melalui rangkaian aktivitas kader meliputi pendataan, penyuluhan, dan kunjungan rumah. Dukungan yang dimiliki kader meliputi dukungan sumber daya manusia (kader dan petugas puskesmas), pelatihan, penyegaran, pengawasan, dana, dan peralatan serta dukungan dari partisipasi masyarakat yang berupa kedatangan ke posyandu. Hambatan yang dialami kader adalah kurangnya partisipasi ibu dalam memberikan ASI eksklusif selama 6 bulan karena dipengaruhi berbagai faktor antara lain pengetahuan ibu, untuk itu kader perlu diberikan penyegaran terhadap materi tentang ASI eksklusif sehingga mendukung pelaksanaan tugas sebagai kader dalam promosi kesehatan yang dilakukan.

\section{KESIMPULAN}

Dari hasil penelitian ini dapat disimpulkan bahwa ada peningkatan ratarata pengetahuan dan sikap kader sebelum dan setelah pelatihan pencegahan pemberian makanan pralaktal dengan menggunakan modul dan ceramah di Wilayah Puskesmas Talang Tinggi Kabupaten Seluma Tahun 2016. Tidak ada 
perbedaan secara statistik pengetahuan dan sikap kader setelah diberikan pelatihan pencegahan pemberian makanan pralaktal dengan menggunakan modul dan leaflet di Wilayah Puskesmas Talang Tinggi Kabupaten Seluma Tahun 2016. Hasil penelitian diharapkan dapat menjadi bahan rekomendasi bagi Pimpinan Puskesmas talang Tinggi dan bidan koordinator serta bidan desa untuk memberikan dalam kegiatan promosi kesehatan kepada kader melalui pelatihan terstruktur menggunakan modul agar pesan promosi yang disampaikan lebih mudah diterima

\section{DAFTAR RUJUKAN}

BPS, 2012 Survei demografi Kesehatan Indonesia, 2012, Jakarta, 2012

Kemenkes RI, 2014, Situasi Dan Analisis ASI Eksklusif, Pusat Data Dan Informasi, Kemenkes RI, Jakarta.

Khanal V, Adhikari M, Sauer K, Zhao Y. Factors associated with the introduction of prelacteal feeds in Nepal: findings from the Nepal Demographic and Health Survey 2011. International Breastfeed Jounal. 2013 Aug 8;8(1):9. doi: 10.1186/1746-4358-8-9.

Tarigan U, NK. Aryastami. 2012. Pengetahuan, Sikap Dan Perilaku Ibu Bayi Terhadap Pemberian Asi Eksklusif. Buletin Penelitian Sistem Kesehatan - Vol. 15 No. 4 Oktober 2012: 390-397

Dwi Nastiti Iswarawanti, 2011, Kader Posyandu: Peranan Dan Tantangan Pemberdayaannya Dalam Usaha Peningkatan Gizi Anak Di Indonesia, Jurnal Manajemen Pelayanan Kesehatan, Vol.13, No.04,Tahun 2011

Novie E Mauliku, Susilowati, Yati Agustini (2014), Faktor-Faktor Yang Berhubungan Dengan Pemberian Makanan Pendamping Asi Dini Pada Bayi 6 - 12 Bulan Di Desa Batujajar Barat Kecamatan Batujajar Kabupaten Bandung Barat Tahun 2008, Jurnal Kesehatan Kartika Stikes A. Yani

Novianti, Anissa Rizkianti, Pemberian Asupan Prelakteal Sebagai Salah Satu Faktor Kegagalan Asi Eksklusif Pada Pekerja Buruh Industri Tekstil Di Jakarta, Jurnal Kesehatan Reproduksi Vol. 5 No 1, April 2013 : 23-36 sehingga dapat meningkatkan pengethauan dan sikap positif kader dalam promosi pencegahan makanan pralktal. Rekomendasi bagi Kepada Dinas Kesehatan diharapkan hasil penelitian ini dapat menjadi masukan dalam menyusun kebijakan dan memberi dukungan bagi kader untuk terlibat dalam kegiatan puskesmas, meningkatkan fungsi pengawasan terhadap pelayanan yang diberikan puskesmas terutama pelayanan kesehatan ibu dan anak sebagai upaya meningkatkan cakupan ASI ekslusif.

Ummu Hanan, Pengalaman Kader Kesehatan Dalam Promosi Kesehatan Tentang Asi Eksklusif Di Posyandu Flamboyan Ii Kelurahan Rempoa Tangerang Selatan, Tahun 2012, Fk Uin Syarif Hidayatullah Jakarta

Rahmadhani. 2012, Penyebab Terputusnya Pemberian Asi Eksklusif Di Kecamatan Rumbai Pesisir Tahun 2011, Fkm Ui, 2012

Jumiyati, Nugrahaeni S A, Ani Margawati , (2014), Pengaruh Modul Terhadap Peningkatan Pengetahuan, Sikap Dan Praktek Kader Dalam Upaya Pemberian Asi Eksklusif, eJournal Persagi, Vol.37 No.1 (2014)

Ni Luh Ayusita Eka Putra, Evaluasi Peran Kader Dalam Upaya Meningkatkan Cakupan Pemberian Asi Eksklusif Di Wilayah

osha, Utami.H.N. 2013 , Determinan Pemberian Makanan Prelaktal Pada Bayi Baru Lahir Di Kelurahan Kebon Kelapa Dan Ciwaringin, Kota Bogor, Jurnal Penelitian Gizi Dan Makanan, Juni 2013 Vol. 36 (1): 54-6

Roesli, U. Insisasi Menyusui Dini Plus ASI Eksklusif. Jakarta: Pustaka bunda.; 2008.

RTi.T.A., Manan W.WM., Isa.B.M 2013, Predicting Early Discontinuation of Ex clusive Breast Feeding among Women in Kelantan malaysia, Health and the Environment Journal, 2013, Vol. 4. No. 01.

Wulandari, Melly. Faktor-Faktor yang Berhubungan dengan Pemberian Makanan Prelakteal pada Bayi Baru Lahir di Desa Supat Timur Kabupaten Musi Banyuasin SumateraSelatan Tahun 2011. FKM UIN: Jakarta; 2011. 